\title{
Community attitudes towards protected areas: insights from Ghana
}

\author{
SELASE DewU and Eivin RøSkAfT
}

\begin{abstract}
Understanding community attitudes towards protected areas is of great importance because these attitudes are inherently linked to the long-term existence and effectiveness of protected areas. We assessed the factors that influence community attitudes towards Mole and Digya National Parks in Ghana. During June-August 2015 we conducted interviews with 346 randomly selected households, using a semi-structured questionnaire. We found that attitudes towards the protected areas were positive, with Mole residents being more positive than Digya residents. Analyses revealed that community attitudes were largely influenced by the perceived costs and benefits of the protected area, household size, occupation, level of education, and awareness of or participation in livelihood projects. The findings suggest that increasing the benefits from protected areas and minimizing the costs on fringe communities fosters positive attitudes towards the concept of protected areas and conservation in general. Additionally, perceptions of protected areas are likely to be more positive when management interventions are tailored for local communities as opposed to the adoption of universal, unspecific interventions.
\end{abstract}

Keywords Benefits, community attitudes, conservation, costs, Digya National Park, Ghana, Mole National Park, protected areas

\section{Introduction}

Cetting aside priority areas for conservation is viewed as a $\checkmark$ crucial strategy in securing dwindling biodiversity (Rodrigues et al., 2004; Geldmann et al., 2013). However, the establishment and maintenance of protected areas is controversial. Although many people regard protected areas as an essential conservation strategy, others perceive them as a threat to their livelihoods (Brockington \& Wilkie, 2015).

The establishment and maintenance of protected areas usually involves restricting access to essential resources, evicting communities living within the new boundaries and modifying traditional land use rights (Wilkie et al., 2010; Cobbinah et al., 2015). In developing countries areas

Selase Dewu (Corresponding author) and Eivin RøsKaft Department of Biology, Norwegian University of Science and Technology, NO-7491, Trondheim, Norway. E-mail dewuselase@gmail.com

Received 16 May 2016. Revision requested 18 July 2016.

Accepted 6 September 2016. First published online 6 February 2017. demarcated for protection are usually surrounded by people who are generally impoverished and whose livelihoods depend on such areas (King, 2010). Restricting access to natural resources can make it difficult for these people to meet their basic livelihood needs (Amoah \& Wiafe, 2012; Cobbinah et al., 2015). This does not inspire collaboration for conservation but instead breeds resentment and apathy (King, 2010; Amoah \& Wiafe, 2012).

Not only does the establishment of protected areas preclude people from resource acquisition, it can sometimes bring untold hardships (Mfunda, 2010; Masud et al., 2014). Local communities may be forced to bear significant losses (e.g. raided crops, depredation of livestock, damage to other property) associated with the management of these areas (Kideghesho \& Mtoni, 2008; Karanth \& Nepal, 2012; Vedeld et al., 2012; Cobbinah, 2015). Restricted resource access coupled with crop damage often leads to negative attitudes (Wang et al., 2006).

Local communities are often excluded from the management of conservation areas, and this exclusion is believed to be a source of conflict (Lewis, 1996). Communities who do not feel they are part of the conservation effort but have to bear the costs of conservation are understandably unsupportive (Gillingham \& Lee, 2003). However, when communities are actively involved they tend to exhibit positive attitudes (Infield \& Namara, 2001), which correlate with conservation success in protected areas (Struhsaker et al., 2005).

A prerequisite for effective management of protected areas is the inclusion of local communities (Nyahongo, 2010). Moreover, effective management also calls for an understanding of people's attitudes and the underlying factors that form these attitudes (Allendorf et al., 2006, 2012; Sarker \& Røskaft, 2011). Understanding attitudes towards conservation and incorporating these into management interventions could further improve attitudes, park-people relationships and conservation in general (Allendorf et al., 2012). We assessed the attitudes of fringe communities towards protected areas in Ghana, using the country's two largest National Parks, Mole and Digya, as case studies. Factors affecting peoples' attitudes were assessed and compared across the two protected areas to identify similarities and differences.

People's attitudes towards protected areas are largely influenced by the perceived costs and benefits of these areas (Allendorf et al., 2006; Tessema et al., 2010). Attitudes tend to be positive when people benefit from a protected area (Infield \& Namara, 2001; Mehta \& Heinen, 2001; 
Scanlon \& Kull, 2009; Cobbinah, 2015). Conversely, if protected areas threaten the livelihoods of the surrounding communities (e.g. if crops are raided by wildlife from the protected area) their attitudes towards the protected area are usually negative (Baral \& Heinen, 2007; Kideghesho et al., 2007; Manyama et al., 2014).

Against this backdrop we hypothesized that households benefiting from a protected area would have more positive attitudes towards the protected area $\left(\mathrm{H}_{1}\right)$. Likewise, considering the potential losses incurred by local people, we hypothesized that households overwhelmed by these losses would have less favourable attitudes towards the protected area $\left(\mathrm{H}_{2}\right)$. There is evidence that livelihood programmes can have a positive effect on people's attitudes and behaviours, making them more amenable to conservation (Abbot et al., 2001). We therefore hypothesized that households that are aware of or have participated in livelihood support projects would have favourable attitudes towards the protected area $\left(\mathrm{H}_{3}\right)$. We also assessed the effects of socioeconomic and demographic variables on attitudes, as they have been found to influence conservation attitudes (Infield \& Namara, 2001; Holmes, 2003; Wang et al., 2006; Karanth \& Nepal, 2012; Sarker \& Røskaft, 2011; Masud \& Kari, 2015).

Literature pertaining to local community attitudes towards protected areas in Ghana is scant. This study is among the first to assess community attitudes towards Mole and Digya National Parks. The findings will broaden our understanding of the factors that influence the attitudes of local residents and could also serve as a baseline for evaluating conservation attitudes in relation to the implementation of new policies.

\section{Study areas}

Ghana has an extensive network of protected areas, spanning a variety of ecosystems, and conservation dates back to the colonial era. The first wildlife policy for the country was adopted in 1974, recognizing the importance of protected areas as a conservation strategy. In 1994 this policy was revised to emphasize the role of communities in wildlife conservation (Ntiamoa-Baidu et al., 2001).

Mole National Park $\left(4,800 \mathrm{~km}^{2}\right)$, in northern Ghana (Fig. 1), is the country's largest National Park. Although protected since 1958, it was not designated a National Park until 1971 (Ntiamoa-Baidu et al., 2001). The habitat is Guinea savannah woodland and the mean annual rainfall is c. 1,000 $\mathrm{mm}$ (Jachmann, 2008; Burton et al., 2011). Over 90, 300 and 740 species of mammals, birds and plants, respectively, are protected within the Park (Forestry Commission of Ghana). There are c. 33 villages in the vicinity (IUCN-PAPACO, 2011b), and these communities are largely engaged in subsistence farming that is seasonal and dependent on rainfall.

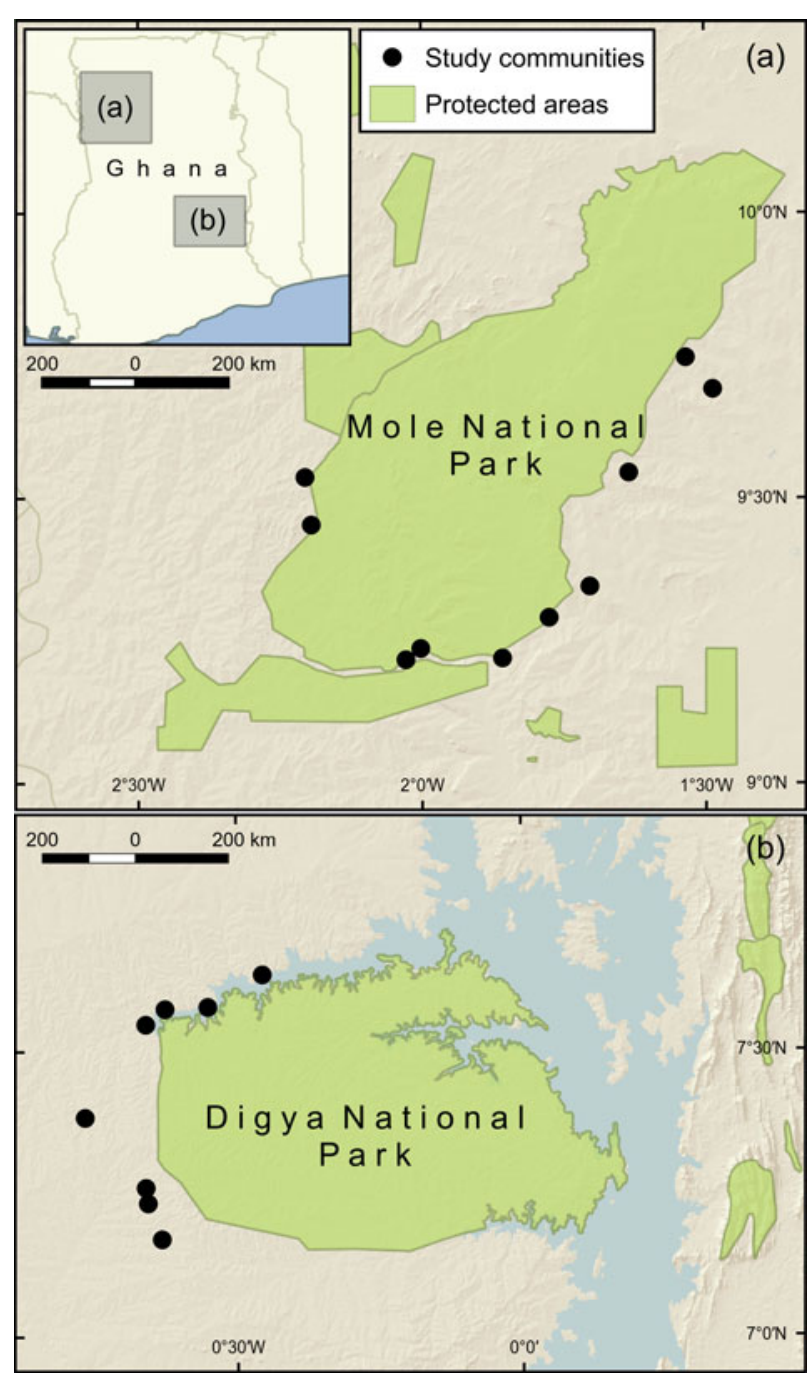

FIG. 1 Locations of communities around (a) Mole and (b) Digya National Parks, Ghana, where interview surveys were conducted to assess local attitudes towards the protected areas.

Digya National Park $\left(3,480 \mathrm{~km}^{2}\right)$, in central Ghana, is the country's second largest National Park (Fig. 1), spanning the Brong Ahafo, and Eastern and Ashanti regions. It is bordered to the east by Lake Volta, to the north by the Sene River and to the south by the Obosum River. Vegetation is largely Guinea savannah woodland and transitional semideciduous forest. Mean reported annual rainfall is 1,200$1,300 \mathrm{~mm}$. The area was first established as a game reserve in 1909 and later expanded and gazetted as a National Park in 1971 (Twumasi et al., 2005). The Park is inhabited by elephants Loxodonta africana, ungulates, manatees Trichechus senegalensis, and primate species, among others (Twumasi et al., 2005; Jachmann, 2008). It is fringed by indigenous and migrant communities that are engaged in farming and fishing. However, there are conflicts between park officials and local communities over where people are permitted to fish. 
These two protected areas are important for conservation in Ghana. Tourism is well established at Mole National Park but not at Digya. Compared to Mole, communities around Digya play virtually no role in the management of the protected area. Furthermore, communities around Mole have benefited more from activities aimed at enhancing livelihoods (IUCN-PAPACO, 2011a,b). Poverty is reported to be the root cause of conflicts between fringe communities and Digya National Park (Ayivor et al., 2013). We are of the opinion that the same is true for communities bordering Mole National Park.

\section{Methods}

\section{Data collection}

Household interviews were conducted using a semistructured questionnaire. We recorded demographic details of the respondents, the perceived costs and benefits of the protected area, and attitudes towards the protected area. We used 12 statements to assess attitudes (Table 1), using a 5-point Likert scale ranging from strongly disagree to strongly agree (Likert, 1932). Attitude is defined as the tendency to act in a particular manner when confronted with a particular object or situation (Oppenheim, 1992), based on evaluations of or opinions about the object or situation (Petty et al., 1997).

Interviews were conducted with a total of 346 randomly selected households during June-August 2015; 196 of the households were from 10 communities around Mole National Park and 150 were from eight communities around Digya National Park. Communities were selected based on discussions with local officials, and are representative of those around the protected areas in terms of distribution of costs and benefits, and local economies. Heads of households were interviewed face-to-face. In their absence, another member of the household over 18 years of age (mostly housewives) was interviewed. In $>90 \%$ of households surveyed the head of the household was male. This resulted in a disproportionately large number of male interviewees. However, most of the interviews were conducted in the presence of female members of the household, who were allowed to contribute. Interviews were conducted mainly in local languages, with the aid of translators. Table 2 presents descriptive statistics of respondents' socio-economic status and demographic characteristics at the two protected areas. Differences between the two areas were explored using $\chi^{2}$ tests.

\section{Data analyses}

Analyses were performed using SPSS v. 23 (IBM, Armonk, USA). To provide a general measure of attitude we summed scores of individual statements to produce a composite attitude score. Prior to the summation, scores of negative statements were reversed to ensure that scoring on all statements was uniform. Thus, high scores on negative statements connote positive attitudes. Scores above the halfway point on the continuum of computed scores (12-60) were considered to be indicators of positive attitudes (Oppenheim, 1992). With this composite attitude scale an independent-sample t-test was conducted to compare the mean attitude scores of households from the two protected areas to determine whether there were significant differences in attitudes.

We performed multiple regression analyses on the attitude scale for both protected areas to assess how demographic variables, as well as costs and benefits, affect attitudes towards the protected areas. Socio-demographic variables included in the regression model were chosen based on their significance in influencing attitudes, as reported in similar studies. These variables were age (Karanth et al., 2008; Masud \& Kari, 2015), years of formal education (Tessema et al., 2010; Manyama et al., 2014), occupation (Khatun et al., 2012; Masud \& Kari, 2015), household size (Tessema et al., 2010), annual household income (Sarker \& Røskaft, 2011; Lepetu \& Garekae, 2015), residency status (Holmes, 2003), alternate form of employment (Nyahongo, 2010; Lepetu \& Garekae, 2015), and awareness of or participation in livelihood support projects (Mehta \& Heinen, 2001; Kideghesho et al., 2007). We used annual household income as a measure of poverty. Households were categorized as either poor $(\leq \mathrm{GHS}$ 2,000) or not poor ( $\geq$ GHS 2,00o). Preliminary analyses were carried out to ensure there were no violations in the assumptions of the multiple regression (Pallant, 2005; Tabachnick \& Fidell, 2013). This led to the logarithmic transformation of household size and annual income. Years of formal education deviated slightly from normal. However, we found no transformation that produced a nearly normal distribution without the loss of values, and therefore we used the untransformed data.

\section{Results}

\section{Household characteristics}

All interviewees were aware of the existence of a protected area within their locality. Of the 346 interviewees, 334 (96.5\%) were male. The mean age of respondents was $48.8 \pm$ SD 15.6 years (median $=47.0$, range $20-101$ ). Approximately $59 \%$ of respondents had received no formal education, $26 \%$ had attained some primary education and $15 \%$ had attained secondary education or higher. The majority of respondents (c. 79\%) were from farming households; $17 \%$ were fishers; and $10 \%$ were engaged in other forms of employment, including employment in the formal sector, petty trading and charcoal burning (some respondents reported more 
TABle 1 Mean scores of attitude statements by local people in communities around Mole and Digya National Parks, Ghana (Fig. 1). Negative statements are in bold; their scores were reversed so that high scores indicate more positive attitudes.

\begin{tabular}{|c|c|c|c|c|}
\hline \multirow[b]{2}{*}{ Attitude statements } & \multirow{2}{*}{$\begin{array}{l}\operatorname{Mole}^{1}(n=190) \\
\text { Mean } \pm \text { SD }\end{array}$} & \multirow{2}{*}{$\begin{array}{l}\operatorname{Digya}^{2}(n=148) \\
\text { Mean } \pm \text { SD }\end{array}$} & \multicolumn{2}{|l|}{ Statistics } \\
\hline & & & $\chi^{2}(\mathrm{df}=4)$ & $\mathrm{P}$ \\
\hline I am happy about the presence of the protected area in my community. & $4.3 \pm 1.4$ & $4.2 \pm 1.2$ & 20.09 & $0.001^{\star}$ \\
\hline The presence of the protected area has improved my living conditions. & $2.4 \pm 1.7$ & $2.6 \pm 1.7$ & 7.61 & 0.107 \\
\hline The presence of the protected area has worsened my situation. & $3.1 \pm 1.9$ & $4.1 \pm 1.5$ & 41.83 & 0.001 \\
\hline The presence of the protected area has brought development to my village. & $2.7 \pm 1.8$ & $1.4 \pm 1.0$ & 56.19 & 0.001 \\
\hline Management of the protected area is effective. & $4.3 \pm 1.1$ & $3.8 \pm 1.3$ & 13.08 & 0.011 \\
\hline The protected area is necessary for protecting the remaining resources. & $4.8 \pm 0.8$ & $4.7 \pm 0.8$ & 19.60 & $0.001^{*}$ \\
\hline People should be allowed to hunt in the protected area. & $4.7 \pm 0.8$ & $4.4 \pm 1.3$ & 13.76 & 0.008 \\
\hline Relationships between the community \& park officials are cordial. & $4.3 \pm 1.2$ & $4.4 \pm 1.1$ & 2.00 & 0.736 \\
\hline Park officials understand \& are concerned about our needs. & $2.0 \pm 1.5$ & $2.4 \pm 1.4$ & 34.72 & 0.001 \\
\hline The community is involved in decision making \& management of the area. & $3.8 \pm 1.5$ & $1.2 \pm 0.7$ & 211.53 & 0.001 \\
\hline We are encouraged to participate in conservation programmes. & $3.9 \pm 1.5$ & $2.6 \pm 1.7$ & 62.06 & 0.001 \\
\hline My personal relationship with the protected area is good. & $4.3 \pm 1.2$ & $4.4 \pm 0.9$ & 23.88 & $0.001^{*}$ \\
\hline
\end{tabular}

${ }^{*}$ Statistically significant, but difference between mean scores is small.

${ }^{1}$ Cronbach's $\alpha=0.77$

${ }^{2}$ Cronbach's $\alpha=0.70$

than one occupation). The mean size of participating households across the study areas was $8.3 \pm$ SD 5.6 people.

Approximately $45 \%$ of respondents stated that they benefited from the protected areas, with benefits including access to non-timber forest products (88.6\%), water (26.6\%) and financial incentives $(14.9 \%)$. Conversely, c. $58 \%$ of respondents stated that they faced problems because of the protected areas. Crop raiding was the most cited problem

TABLE 2 Characteristics of respondents from communities around Mole and Digya National Parks, Ghana (Fig. 1), with results of $\chi^{2}$ tests showing differences between the two areas.

\begin{tabular}{|c|c|c|c|c|c|}
\hline \multirow[b]{2}{*}{ Variable } & \multicolumn{2}{|c|}{ Protected area } & \multicolumn{3}{|c|}{ Statistics } \\
\hline & Mole (\%) & Digya (\%) & $\overline{\chi^{2}}$ & $\mathrm{df}$ & $\mathrm{P}$ \\
\hline Age (years) & & & 6.17 & 2 & 0.046 \\
\hline$\leq 39$ & 27.1 & 33.6 & & & \\
\hline $40-59$ & 40.1 & 45.6 & & & \\
\hline$\geq 60$ & 32.8 & 20.8 & & & \\
\hline Household size & & & 47.69 & 1 & 0.001 \\
\hline$\leq 7$ & 40 & 77.9 & & & \\
\hline$>7$ & 60 & 22.1 & & & \\
\hline Annual income (GHS) & & & 6.90 & 1 & 0.009 \\
\hline$\leq 2,000$ & 68 & 52.8 & & & \\
\hline$>2,000$ & 32 & 47.2 & & & \\
\hline Formal education & & & 47.83 & 2 & 0.001 \\
\hline None & 74.7 & 38 & & & \\
\hline Primary & 14.9 & 41.3 & & & \\
\hline Secondary or higher & 10.3 & 20.7 & & & \\
\hline Occupation & & & 127.53 & 2 & 0.001 \\
\hline Farmer & 90.7 & 63.3 & & & \\
\hline Fisher & & 38.7 & & & \\
\hline Other & 9.8 & 10.6 & & & \\
\hline Benefit from protected area & & & 6.05 & 1 & 0.014 \\
\hline Yes & 50.5 & 36.7 & & & \\
\hline No & 49.5 & 63.3 & & & \\
\hline Problems from protected area & & & 56.45 & 1 & 0.001 \\
\hline Yes & 75.5 & 34.7 & & & \\
\hline No & 24.5 & 65.3 & & & \\
\hline Residency & & & 185.97 & 1 & 0.001 \\
\hline Native & 85.7 & 11.3 & & & \\
\hline Migrant & 14.3 & 88.7 & & & \\
\hline
\end{tabular}


( $87 \%$ of responses), followed by restricted access, conflicts with officials, and depredation of livestock, which summed to $18.5 \%$ of cases. As each respondent was allowed to give multiple responses, these percentages do not sum to $100 \%$. Respondents' characteristics in each of the two protected areas are in Table 2.

\section{Attitudes towards protected areas}

The attitude scale reliability index was 0.73 for both protected areas (Table 1). Interviewed households had a mean attitude score of $42.60 \pm \mathrm{SE} 0.47$, indicating mild positive attitudes towards the protected areas. Households around Mole National Park had a mean score of $44.56 \pm$ SE 0.66 , and households around Digya National Park had a mean score of $40.07 \pm \mathrm{SE}$ o.61. Attitude scores were statistically different between the two areas $\left(t_{(335)}=5.02, \mathrm{P}<0.001\right)$. Although this analysis inferred mildly positive attitudes towards the protected areas, not all households shared the same views. Approximately $24 \%$ ( 82 households) expressed negative attitudes.

\section{Factors influencing attitudes towards protected areas}

For households around Mole National Park, $22.7 \%$ of the variation in attitudes was explained by the regression model $\left(F_{(10,153)}=4.48, \mathrm{P}<0.001\right)$. Benefits $(\mathrm{P}=0.002)$, problems $(\mathrm{P}=0.017)$ and household size $(\mathrm{P}=0.029)$ significantly affected attitudes. Households that held positive attitudes were likely to be small in size and to have benefited from the protected area and encountered few if any problems with the protected area (Table 3).

For households around Digya National Park, the regression model helped explain c. $23 \%$ of the variance in attitudes $\left(F_{(10,130)}=3.85, \mathrm{P}<0.001\right)$. Households expressing positive attitudes were likely to have benefited from the protected area $(\mathrm{P}<0.001)$ and encountered no problems with the protected area $(\mathrm{P}=0.002)$. They were also likely to be farmers $(\mathrm{P}=0.037$; Table 3$)$.

For both protected areas, problems, benefits, protected area, household size, occupation, awareness of livelihood support projects and education were significant in influencing attitudes $(\mathrm{P}<0.05)$. Together, these variables explained $25.2 \%$ of the variation in attitudes $\left(F_{(11,292)}=8.95, \mathrm{P}<0.001\right)$. Despite findings elsewhere, we found no evidence that income, age, residency status or alternative means of employment significantly affected attitudes (Table 3).

\section{Discussion}

\section{Attitudes towards protected areas}

Generally, local communities were mildly positive towards the protected areas and conservation in general. This may be attributable to their understanding that protected areas are necessary for the protection of resources. However, although communities regarded the protected areas as essential, they neither improved their living conditions markedly nor brought any major development to the communities (Table 1). The perceived lack of understanding and concern among park officials for the needs of the communities could also explain why attitudes were only marginally positive.

Although household attitudes were mildly positive across the two protected areas, residents around Mole National Park were more positive. We believe this disparity may be explained by the level of engagement of the communities in decision making and management of the protected areas (Table 1). It may also be attributable to unresolved conflicts between protected area management authorities and fringe communities around Digya National Park (Ayivor et al., 2013), which make it difficult to foster harmonious park-people relationships (Infield \& Namara, 2001). Protected areas themselves (e.g. local conditions, management interventions) are vital predictors of attitudes (Karanth \& Nepal, 2012; Allendorf et al., 2012), as supported by our regression results. Our findings suggest that an exclusive and militaristic approach to protected area management, such as that used in Digya, may not augur well for conservation in general.

\section{Factors influencing attitudes towards protected areas}

This study was based on the assumption that attitudes are largely influenced by perceived costs and benefits, and regression analyses for both National Parks emphasized the importance of perceived costs and benefits in influencing attitudes towards conservation (Table 3). This finding is congruent with similar studies conducted elsewhere (Gillingham \& Lee, 1999; Holmes, 2003; Kideghesho et al., 2007; Tessema et al., 2010). The results affirm that receiving benefits elicits favourable attitudes $\left(\mathrm{H}_{1}\right)$ and therefore makes people more acquiescent to the concept of protected areas. It also gives credence to the hypothesis that households experiencing losses have less favourable attitudes ( $\mathrm{H}_{2}$; Table 3 ).

It is reported that the achievement of positive conservation outcomes is more likely when local communities receive socioeconomic benefits from conservation initiatives (Oldekop et al., 2016). Considering this, conservation policies need to ensure that communities receive tangible benefits from protected areas if they are to wholly or partly support conservation. These benefits must outweigh the perceived costs (Scanlon \& Kull, 2009) and address the needs of the people (Kideghesho \& Mtoni, 2008).

Regarding H2, Kideghesho et al. (2007) conversely reported that people experiencing minimal conflicts or losses were more positive than their counterparts. The majority of 
TABLE 3 Results of multiple regression analyses showing the effects of predictor variables on attitudes around the two protected areas (some households were excluded because of incomplete responses to the questionnaire). For analysis across the two protected areas, the areas themselves were included as predictor variables.

\begin{tabular}{|c|c|c|c|c|c|c|c|c|c|}
\hline \multirow[b]{2}{*}{ Variable $^{1}$} & \multicolumn{3}{|c|}{ Mole $(\mathrm{n}=163)^{2,3}$} & \multicolumn{3}{|c|}{ Digya $(n=140)^{2,4}$} & \multicolumn{3}{|c|}{$\begin{array}{l}\text { Both protected areas } \\
(\mathrm{N}=303)^{2,5}\end{array}$} \\
\hline & $\beta$ & $\mathrm{P}$ & $\mathrm{Sr}^{2}$ & $\beta$ & $\mathrm{P}$ & $\mathrm{Sr}^{2}$ & $\beta$ & $\mathrm{P}$ & $\mathrm{Sr}^{2}$ \\
\hline Benefit (No) & 0.242 & 0.002 & 0.049 & 0.293 & $<0.001$ & 0.080 & 0.262 & $<0.001$ & 0.063 \\
\hline Problem (No) & -0.200 & 0.017 & 0.029 & -0.262 & 0.002 & 0.061 & -0.215 & $<0.001$ & 0.034 \\
\hline Protected area (Mole) & & & & & & & -0.294 & 0.003 & 0.023 \\
\hline Household size (log) & -0.174 & 0.029 & 0.024 & -0.083 & 0.322 & & -0.156 & 0.009 & 0.018 \\
\hline Occupation (Non farmer) & 0.101 & 0.232 & & 0.175 & 0.037 & 0.026 & 0.142 & 0.013 & 0.016 \\
\hline Livelihood project (No) & 0.134 & 0.072 & & 0.076 & 0.360 & & 0.182 & 0.019 & 0.014 \\
\hline Education & 0.070 & 0.378 & & 0.141 & 0.095 & & 0.118 & 0.035 & 0.011 \\
\hline Alternate employment (No) & 0.098 & 0.199 & & 0.045 & 0.590 & & 0.100 & 0.062 & \\
\hline Annual income (log) & 0.068 & 0.394 & & 0.139 & 0.099 & & 0.067 & 0.234 & \\
\hline Residency (Migrant) & -0.142 & 0.062 & & 0.164 & 0.051 & & -0.056 & 0.463 & \\
\hline Age & 0.023 & 0.774 & & -0.014 & 0.861 & & 0.012 & 0.819 & \\
\hline
\end{tabular}

${ }^{1}$ The direction of predictor variables, or the type of transformation in the case of Household size and Annual income, are indicated in parentheses.

${ }^{2} \beta$, standardized regression coefficient; $\mathrm{P}$, statistical significance; $\mathrm{Sr}^{2}$, unique contribution of variable to total variance.

${ }^{3} R=0.476 ; R^{2}=0.227$; Adjusted $R^{2}=0.176$

${ }^{4} R=0.478 ; R^{2}=0.228 ;$ Adjusted $R^{2}=0.169$

${ }^{5} R=0.502 ; R^{2}=0.252$; Adjusted $R^{2}=0.223$

households around Mole National Park reported more problems than households around Digya National Park (Table 2); the disparity between losses and attitudes in this case may be explained by the fact that benefits received by Mole residents may have offset the costs.

Problems and benefits were the most significant variables influencing attitudes in both of the study areas. Household size significantly influenced attitudes in Mole but not in Digya. Considering the two areas as a unit in an attempt to identify a general pattern as to which factors were likely to influence attitudes, household size correlated negatively with attitudes. A similar finding was reported from Zimbabwe (Mutanga et al., 2015). Larger households tend to require more resources from protected areas and not to perceive conservation as an optimal land-use option, which probably explains their apathy.

The occupation of respondents significantly influenced attitudes around Digya but not around Mole, where nonfarmers appeared to be less favourable towards the protected area. A large proportion of non-farmers are fishers and they are in constant conflict with park officials as a result of restrictions on fishery resource acquisition. Digya National Park is largely surrounded by water, with boundaries extending into the water, and most fishers knowingly or unknowingly drift into the Park. Punitive sanctions are applied, which creates a sense of antagonism and resentment towards Park officials and towards the Park in general. Similar findings were reported by Ayivor et al. (2013). Such altercations and the negative attitudes they engender could also explain the variation in attitudes between Mole and Digya National Parks.
On the whole, households that were aware of or had participated in livelihood projects exhibited positive attitudes (Table 3). This finding is in accordance with our hypothesis $\mathrm{H}_{3}$. People can lose their livelihoods when conservation areas are established and this can incite negative sentiments. Conversely, when livelihoods are secured through conservation, attitudes are often positive. This underscores the need to make more livelihood-relevant projects and schemes available to local communities. However, the establishment of such programmes must include inputs from local people, as projects have reportedly been abandoned because local inputs were not sought or adequately factored in (Cobbinah et al., 2015).

The other factor affecting community attitudes in the study areas was education. Other studies (Kideghesho et al., 2007; Manyama et al., 2014; Masud \& Kari, 2015; Mutanga et al., 2015) also reported a correlation between the level of education and conservation attitudes. Bettereducated people may be better able to understand the role of protected areas in conservation, as well as the environmental services they provide (Tessema et al., 2010; Allendorf et al., 2012). There is a need for more conservation-related education in communities bordering conservation areas.

This study had some limitations. Firstly, regardless of their status as important conservation areas, Mole and Digya National Parks are not representative of all conservation areas in Ghana, and therefore extrapolation of these findings to other areas should be undertaken with caution. Secondly, the components and variables from which attitudes were inferred are not all-inclusive. Thirdly, the 
differences in attitude scores between the two areas could be a result of sampling anomalies. The presence of fishers may have lowered the overall attitude score of residents around Digya National Park.

To conclude, this study examined attitudes of surrounding communities towards two protected areas in Ghana. The results depict mildly positive attitudes across the conservation areas, with residents around Mole more positive than those around Digya. Attitudes were largely dependent on losses and benefits. On this basis we subscribe to the notion that most of the prevailing conflicts between local communities and protected areas can be resolved if benefits are extended to local people and/or if negative impacts associated with living close to protected areas are mitigated (Lewis, 1996). We also found that awareness of or participation in livelihood support projects had positive effects on attitudes. Furthermore, prevailing local conditions in each of the protected areas significantly influenced attitudes.

Achieving conservation goals while meeting the resource and livelihood needs of local communities is challenging but not impossible. Based on our findings we recommend the following to improve the relationships between the authorities of these two parks in Ghana and the neighbouring communities: (1) management could capitalize on their cordial relationship with local communities (Table 1 ) and actively engage them in conservation, and (2) policies and projects that have a direct impact on people's livelihoods, and park-people relations, could be given prime consideration. If these recommendations could be incorporated into management programmes, a future reassessment of community attitudes could be undertaken to ascertain whether the desired attitudinal changes had occurred. A longitudinal study taking into consideration other factors that are likely to influence peoples' attitudes towards conservation would also be useful. To facilitate these matters, our findings and recommendations will be passed to the relevant authorities of the two protected areas.

\section{Acknowledgements}

We thank Newton Seidu and Richard Asare of Mole National Park and Emmanuel Nimo and Mohammed Issifu of Digya National Park for their help during data collection, and all of the respondents who took time to provide us with information. We also acknowledge the constructive comments provided by Martin Fisher and two anonymous reviewers.

\section{Author contributions}

SD and ER designed the study. SD collected and analysed the data, and wrote the article with support from ER.

\section{References}

Аввот, J.I.O., Thomas, D.H.L., Gardner, A.A., Neba, S.E. \& Khen, M.W. (2001) Understanding the links between conservation and development in the Bamenda Highlands, Cameroon. World Development, 29, 1115-1136.

Allendorf, T.D., Aung, M. \& Songer, M. (2012) Using residents' perceptions to improve park-people relationships in Chatthin Wildlife Sanctuary, Myanmar. Journal of Environmental Management, 99, 36-43.

Allendorf, T.D., Swe, K.K., Oo, T., Htut, Y., Aung, M., Aung, M. et al. (2006) Community attitudes toward three protected areas in Upper Myanmar (Burma). Environmental Conservation, 33, 344-352.

Amoah, M. \& Wiafe, E.D. (2012) Livelihoods of fringe communities and the impacts on the management of conservation area: the case of Kakum National Park in Ghana. International Forestry Review, 14, 131-144.

Ayivor, J.S., Gordon, C. \& Ntiamoa-Baidu, Y. (2013) Protected area management and livelihood conflicts in Ghana: a case study of Digya National Park. Parks, 19, 37-50.

Baral, N. \& Heinen, J.T. (2007) Resources use, conservation attitudes, management intervention and park-people relations in the Western Terai landscape of Nepal. Environmental Conservation, $34,64-72$.

Brockington, D. \& Wilkie, D. (2015) Protected areas and poverty. Philosophical Transactions of the Royal Society B, 370, 20140271.

Burton, A.C., Buedi, E.B., Balangtaa, C., Kpelle, D.G., Sam, M. K. \& Brashares, J.S. (2011) The decline of lions in Ghana's Mole National Park. African Journal of Ecology, 49, 122-126.

Соввіnaн, P.B. (2015) Local attitudes towards natural resources management in rural Ghana. Management of Environmental Quality, 26, 423-436.

Cobbinah, P.B., Black, R. \& Thwaites, R. (2015) Biodiversity conservation and livelihoods in rural Ghana: impacts and coping strategies. Environmental Development, 15, 79-93.

Forestry Commission of Ghana Mole National Park. Http://www. fcghana.org/page.php? page $=268 \&$ section $=32 \&$ typ $=1 \&$ subs $=270$ [accessed 8 February 2016].

Geldmann, J., Barnes, M., Coad, L., Craigie, I.D., Hockings, M. \& BURGESS, N.D. (2013) Effectiveness of terrestrial protected areas in reducing habitat loss and population declines. Biological Conservation, 161, 230-238.

Gillingham, S. \& Lee, P.C. (1999) The impact of wildlife-related benefits on the conservation attitudes of local people around the Selous Game Reserve, Tanzania. Environmental Conservation, 26, 218-228.

Gillingham, S. \& Lee, P.C. (2003) People and protected areas: a study of local perceptions of wildlife crop-damage conflict in an area bordering the Selous Game Reserve, Tanzania. Oryx, 37, 316-325.

Holmes, C.M. (2003) The influence of protected area outreach on conservation attitudes and resource use patterns: a case study from western Tanzania. Oryx, 37, 305-315.

Infield, M. \& Namara, A. (2001) Community attitudes and behaviour towards conservation: an assessment of a community conservation programme around Lake Mburo National Park, Uganda. Oryx, 35, 48-60.

IUCN-PAPACO (2011a) Management Effectiveness Tracking Tool (METT)_Digya National Park. Http://papaco.org/wp-content/ uploads/2015/o9/METT-Digya_En-final.pdf [accessed 8 February 2016].

IUCN-PAPACO (2011b) Management Effectiveness Tracking Tool (METT) -Mole National Park. Http://papaco.org/wp-content/uploads/ 2015/o9/METT-Mole_En_final.pdf [accessed 8 February 2016]. 
JaCHMAnN, H. (2008) Monitoring law-enforcement performance in nine protected areas in Ghana. Biological Conservation, 141, 89-99.

Karanth, K.K., Kramer, R.A., Qian, S.S. \& Christensen, JR, N.L. (2008) Examining conservation attitudes, perspectives, and challenges in India. Biological Conservation, 141, 2357-2367.

Karanth, K.K. \& NePAL, S.K. (2012) Local residents' perception of benefits and losses from protected areas in India and Nepal. Environmental Management, 49, 372-386.

Khatun, U.H., Ahsan, M.F. \& Røskaft, E. (2012) Attitudes of the local community towards the conservation of the common langur (Semnopithecus entellus) in Keshabpur, Bangladesh. International Journal of Biodiversity and Conservation, 4, 385-399.

Kideghesho, J.R. \& Mtoni, P.E. (2008) Who compensates for wildlife conservation in Serengeti? International Journal of Biodiversity Science \& Management, 4, 112-125.

Kideghesho, J.R., Røskaft, E. \& Kaltenborn, B.P. (2007) Factors influencing conservation attitudes of local people in Western Serengeti, Tanzania. Biodiversity \& Conservation, 16, 2213-2230.

KING, B. (2010) Conservation geographies in sub-Saharan Africa: the politics of national parks, community conservation and peace parks. Geography Compass, 4, 14-27.

Lepetu, J.P. \& Garekae, H. (2015) Attitudes of local communities towards forest management practices in Botswana: the case study of Kasane Forest Reserve. International Journal of Agriculture and Forestry, 5, 138-145.

LEw Is, C. (1996) Managing Conflicts in Protected Areas. IUCN, Gland, Switzerland, and Cambridge, UK.

Likert, R. (1932) A technique for the measurement of attitudes. Archives of Psychology, 22, 5-55.

Manyama, F., Nyahongo, J.W. \& Røskaft, E. (2014) Factors affecting attitudes of local people toward the red-billed quelea (Quelea quelea) in Kondoa District, Tanzania. International Journal of Biodiversity and Conservation, 6, 138-147.

Masud, M.M. \& KARI, F.B. (2015) Community attitudes towards environmental conservation behaviour: an empirical investigation within MPAs, Malaysia. Marine Policy, 52, 138-144.

Masud, M.M., Kari, F.B., YahayA, S.R.B. \& Al-Amin, A.Q. (2014) Impact of residents' livelihoods on attitudes towards environmental conservation behaviour: an empirical investigation of Tioman Island Marine Park area, Malaysia. Ocean \& Coastal Management, 93, 7-14.

Menta, J.N. \& Heinen, J.T. (2001) Does community-based conservation shape favourable attitudes among locals? An empirical study from Nepal. Environmental Management, 28, 165-177.

Mfunda, I.M. (2010) Benefit and cost sharing in collaborative wildlife management in eastern and southern Africa: country experiences, lessons and challenges. In Conservation of Natural Resources. Some African and Asian Examples. (eds E.J. Gereta \& E. Røskaft), pp. 166185. Tapir Academic Press, Trondheim, Norway.

Mutanga, C.N., Vengesayi, S., Gandiwa, E. \& Muboko, N. (2015) Community perceptions of wildlife conservation and tourism: a case study of communities adjacent to four protected areas in Zimbabwe. Tropical Conservation Science, 8, 564-582.

Ntiamoa-Baidu, Y., Owusu, E.H., Daramani, D.T. \& Nuoh, A.A. (2001) Ghana. In Important Bird Areas in Africa and Associated Islands: Priority Sites for Conservation (eds L.D. Fishpool \& M.I. Evans), pp. 367-389. BirdLife International, Cambridge, UK.

Nyahongo, J.W. (2010) The source-sink concept in the conservation of African ungulates: importance and impact of bush meat utilisation from Serengeti, Tanzania, and other protected areas in Africa. In Conservation of Natural Resources. Some African and Asian Examples (eds E.J. Gereta \& E. Røskaft), pp. 237-254. Tapir Academic Press, Trondheim, Norway.

Oldekop, J.A., Holmes, G., Harris, W.E. \& Evans, K.L. (2016) A global assessment of the social and conservation outcomes of protected areas. Conservation Biology, 30, 133-141.

Oppenheim, A.N. (1992) Questionnaire Design, Interviewing, and Attitude Measurement, New edition. Pinter, London, UK.

Pallant, J. (2005) SPSS Survival Manual: A Step by Step Guide to Data Analysis Using SPSS for Windows (Version 12). Allen \& Unwin Pty, Crows Nest, Australia.

Petty, R.E., Wegener, D.T. \& Fabrigar, L.R. (1997) Attitudes and attitude change. Annual Review of Psychology, 48, 609-647.

Rodrigues, A.S.L., Akcakaya, H.R., Andelman, S.J., Bakarr, M.I., BoItAni, L., Brooks, T.M. et al. (2004) Global gap analysis: priority regions for expanding the global protected-area network. BioScience, 54, 1092-1100.

SARKer, A.H.M.R. \& Røskaft, E. (2011) Human attitudes towards the conservation of protected areas: a case study from four protected areas in Bangladesh. Oryx, 45, 391-40o.

SCAnlON, L.J. \& KulL, C.A. (2009) Untangling the links between wildlife benefits and community-based conservation at Torra Conservancy, Namibia. Development Southern Africa, 26, 75-93.

Struhsaker, T.T., Struhsaker, P.J. \& Siex, K.S. (2005) Conserving Africa's rain forests: problems in protected areas and possible solutions. Biological Conservation, 123, 45-54.

TabaChnick, B.G. \& Fidell, L.S. (2013) Using Multivariate Statistics. 6 th edition. Pearson, Boston, USA.

Tessema, M.E., Lilieholm, R.J., Ashenafi, Z.T. \& LEADER-Williams, N. (2010) Community attitudes toward wildlife and protected areas in Ethiopia. Society and Natural Resources, 23, 489-506.

Twumasi, Y.A., Coleman, T.L. \& Manu, A. (2005) Biodiversity management using remotely sensed data and GIS technologies: the case of Digya National Park, Ghana. Proceedings of the 31st International Symposium on Remote Sensing of Environment (ISRSE).

Vedeld, P., Jumane, A., Wapalila, G. \& Songorwa, A. (2012) Protected areas, poverty and conflicts: a livelihood case study of Mikumi National Park, Tanzania. Forest Policy and Economics, 21, 20-31.

Wang, S.W., Lassoie, J.P. \& Curtis, P.D. (2006) Farmer attitudes towards conservation in Jigme Singye Wangchuck National Park, Bhutan. Environmental Conservation, 33, 148-156.

Wilkie, D.S., Redford, K.H. \& McShane, T.O. (2010) Taking of rights for natural resource conservation: a discussion about compensation. Journal of Sustainable Forestry, 29, 135-151.

\section{Biographical sketches}

SELASE DEWU is a biologist interested in the conservation and management of natural resources. EIvin RøsKAFT specializes in evolutionary biology and conservation and is interested in understanding the exploitation of natural resources in light of evolution and human behaviour. He is also interested in the coevolution of avian brood parasites and their hosts. 